\title{
Construction and Building MATERIALS
}

\section{Usage of cement kiln dust in cement products - Research review and preliminary investigations}

\author{
M. Maslehuddin a, ${ }^{\mathrm{a},}$, O.S.B. AI-Amoudi b ${ }^{\text {, }}$ M. Shameem ${ }^{\text {a }}$, M.K. Rehman ${ }^{\text {a }}$, M. Ibrahim a \\ ${ }^{\text {a }}$ Center for Engineering Research, Research Institute, King Fahd University of Petroleum and Minerals, Dhahran 31261, Saudi Arabia \\ ${ }^{\mathrm{b}}$ Department of Civil Engineering, King Fahd University of Petroleum and Minerals, Dhahran 31261, Saudi Arabia
}

Received 19 February 2006; received in revised form 3 September 2007; accepted 5 September 2007

Available online 7 November 2007

\begin{abstract}
Large quantity of dust, commonly known as cement kiln dust (CKD), is produced during the production of Portland cement. In order to meet environmental requirements, CKD is disposed off in land fills. Recently, there has been a trend of utilizing it for soil stabilization, treatment of sewage, etc. Also, attempts were made at using it in cement products. This paper reviews the work conducted on the latter aspect and reports results of tests conducted by the authors to investigate the properties of cement-CKD combination. Results indicate that CKD does not adversely affect the properties of cement mortar. However, the implication of high chloride concentration and alkalinity of CKD on concrete durability needs to be studied.
\end{abstract}

(C) 2007 Elsevier Ltd. All rights reserved.

Keywords: Cement; Kiln dust; Concrete; Cement products

1. Introduction

As the raw feed travels through the Portland cement kiln system, particulates of the raw materials, partially processed feed, and components of the final product are entrained in the combustion gases flowing countercurrent to the feed. These particulates and combustion gas precipitates, collected in the control devices (e.g., cyclone, bag house, or electrostatic precipitator), are collectively referred to as CKD. Usually 98$100 \%$ of all particulate matter generated during cement production is captured by air pollution control devices. In general, CKD is a very heterogeneous mix both by chemistry and particulate size, and these characteristics are dependent on the raw materials, fuels, kiln pyro-processing type, overall equipment layout, and type of cement being manufactured.

Typical chemical composition of CKD and Portland cement in UK are given in Table I [1]. The chemical com-

\footnotetext{
- Corresponding author. Tel.: +966 38602853; fax: +966 38603996 E-mail address:muddin@kfupm.edu.sa (M. Maslehuddin).
}

position may, however, vary with the type of the raw materials and the cement manufacturing processes. The level and variability of the loss on ignition of the CKD reflects the varying amounts of decarburization of the calcium carbonate in the clinker-making raw materials. Being volatile, sulfates, alkalis, and chlorides are preferentially drawn towards the CKD.

With modern manufacturing techniques, it is technically possible to introduce most CKD back into the clinkermaking cycle. However, it is not done due to the restrictions on the alkali content in the cement. Most international specifications restrict the alkali content in cement to less than $0.6 \%$ to avoid the possibility of alkali-aggregate reactivity. It is estimated that over 200,000 tons a year of landfill space could be saved in UK if the surplus CKD could be recycled into the clinker-making process or if alternative uses could be found [1]. It is also calculated that the lost energy in CKD is equivalent to an annual $\mathrm{CO}_{2}$ emission of 80,000 tons.

Approximately 15 million tons of CKD is produced annually by the American cement industry [2]. A medium size cement plant may produce up to 30,000 ton of CKD 
Table 1

Typical chemical composition of CKD and Portland cement [1]

\begin{tabular}{llc}
\hline Constituent & CKD $(\%)$ & Ordinary Portland cement $(\%)$ \\
\hline $\mathrm{SiO}_{2}$ & $11-16$ & 22 \\
$\mathrm{Al}_{2} \mathrm{O}_{3}$ & $3-6$ & 5 \\
$\mathrm{Fe}_{2} \mathrm{O}_{3}$ & $1-4$ & 3 \\
$\mathrm{CaO}$ & $38-50$ & 64 \\
$\mathrm{MgO}$ & $0-2$ & 1 \\
$\mathrm{SO}_{3}$ & $4-18$ & 3 \\
$\mathrm{~K}_{2} \mathrm{O}$ & $3-13$ & $<1$ \\
$\mathrm{Na}_{2} \mathrm{O}$ & $0-2$ & $<1$ \\
$\mathrm{Cl}$ & $0-5$ & $<0.1$ \\
Loss on ignition & $5-25$ & 1 \\
Free CaO & $1-10$ & 2 \\
\hline
\end{tabular}

annually. Based on an analysis of existing data, including data collected by the Portland Cement Association (PCA) from operators of cement manufacturing facilities, it is estimated that in 1995 the cement industry had a clinker capacity of 77 million metric ton and a net CKD generation of 4.08 million metric ton which was disposed in land fills. The 1995 data indicate that 24 of the 110 cement plants $(22 \%)$ recycle all collected CKD back to the kiln, and an additional 12 plants (11\%) ship all the generated CKD for beneficial use. PCA estimated that the remaining two-thirds of cement plants ( 74 facilities) had a combined annual CKD land-disposal requirement of 3.3 million metric ton in 1995.

The obvious and best use of CKD is its re-incorporation in the clinker production cycle. However, this can only be done when the existing restrictions on the alkali and chloride concentration in cement are revised. From alkali point of view, it is estimated that most of the CKD could be utilized in the clinker-making process if the cement alkali levels could be raised by around $0.1 \%$. Similarly, the limits on the required chloride concentration on the performance of cement in reinforced concrete construction need to be evaluated. $[3]:$

Alternative applications of CKD include the following

- Agriculture: potash/lime source and animal feed.

- Civil engineering: fill, soil stabilization, fly ash stabilization, and blacktop filler.

- Building materials: lightweight aggregates, blocks, lowstrength concrete, and masonry cement.

- Sewage and water treatment: coagulation aid and sludge stabilization.

- Pollution control: sulfur absorbent, waste treatment, and solidification.

\section{Previous works}

El-Sayed et al. [4] investigated the effect of CKD on the compressive strength of cement paste and on the corrosion behavior of embedded reinforcement. The study reported that up to $5 \%$ substitution of CKD by weight of cement had no adverse effect on cement paste strength and on reinforcement passivity. A similar conclusion was reached in an investigation conducted by Batis et al. [5] where it was found that when CKD and blast furnace slag are added in proper ratio to ordinary Portland cement, the compressive strength and the corrosion-resistance of the mix increase.

Bhatty [6-8] studied binary, ternary, and quaternary mixes using ordinary Portland cement (OPC), five different CKDs, two different types of fly ash (FA) (Class F and C), and slag. He observed that cements containing CKD alone had reduced strength, setting time, and workability. The addition of FA to a CKD-OPC system lowered the alkali content and resulted in improved strength. Dyer et al. [9] examined ternary blends containing two types of CKD, FA, and OPC, and they found that CKD accelerated the hydration of the binder.

Abo-El-Enien [10] studied the utilization of CKD in the cement industry and building products. CKD was used as a partial substitute of blast furnace slag cement. Strength development in Portland cement pastes with the addition of kiln meal and CKD was investigated. The results showed a high degree of hydration and lower compressive strength than the addition of free cement.

Sri Ravindrarajah [11] reported results of an investigation into the usage of CKD in concrete, as a partial replacement of cement. The percentages of cement replacement by weight were $0,25,50,75$, and 100 in cement paste and 0 , $15,25,35$, and 45 in both $1: 1.5: 3$ and $1: 2: 4$ concretes. The results showed that $C K D$ is a cementitious material and it causes the following effects when used as a replacement of cement:

- retards the setting;

- increases the water demand for a constant consistency; and

- decreases the strength.

The authors further reported that for the same workability concrete, cement can be replaced by up to 15 per cent with CKD without causing a significant strength loss [11].

Wang et al. [12] studied the effects of curing temperature and $\mathrm{NaOH}$ addition on hydration and strength development of CKD-FA binders. Pastes prepared with $50 \%$ $\mathrm{CKD}$ and $50 \% \mathrm{FA}$, having $0 \%, 2 \%$, and $5 \% \mathrm{NaOH}$ addition, and cured at temperatures of 24,38 , and $50^{\circ} \mathrm{C}$ were evaluated. The hydration products of the binders were examined by thermogravimetric analysis (TGA) and $\mathrm{X}$-ray diffraction (XRD) technique. The results indicated that the major crystalline hydration product of the CKDFA binders was ettringite, and it was stable in the CKDFA system at the age of over 100 days. Curing at elevated temperature was more effective for CKD-FA binder strength improvement than $\mathrm{NaOH}$ addition, the later often depressing the ettringite formation in a CKD-FA system. The authors indicated that at a proper curing temperature 
$\left(38^{\circ} \mathrm{C}\right)$, addition of a small amount of $\mathrm{NaOH}(2 \%)$ may increase CKD-FA binder strength; while at a high curing temperature $\left(50^{\circ} \mathrm{C}\right)$ it may reduce the binder strength [12].

Salem and Ragai [13] investigated the electrical conductivity of granulated slag - CKD - silica fume pastes at different porosities. Blended cement pastes containing granulated slag, CKD, made with and without silica fume, were prepared using the initial water-to-solid $(\mathrm{w} / \mathrm{s})$ ratios of $0.30,0.40$, and 0.50 to produce low-, normal-, and highporosity pastes, respectively. The variations of electrical conductivity with hydration time were measured at $30^{\circ} \mathrm{C}$ and $50^{\circ} \mathrm{C}$ for each paste during setting and hardening processes after gauging with deionized water.

Five dry mixtures were prepared using slag:CKD (raw or washed) of $80: 20$ (by weight) and containing $0 \%, 2 \%$, $5 \%, 10 \%$, and $20 \%$ active silica fume as a partial replacement of slag. For conductivity measurements, the blended cement pastes were made with different initial porosities using the $\mathrm{w} / \mathrm{s}$ ratios of $0.30,0.40$, and 0.50 by weight.

It was reported that the changes in electrical conductance reflect the physical and chemical changes taking place in the blended cement paste and can be used as an indication of the setting characteristics of the hardened pastes. Addition of silica fume lead to an increase in the initial conductivity values as well as a shift of the conductivity peaks to longer times of hydration; this effect was mainly related to the relatively high hydraulic reactivity of silica fume compared with granulated slag.

By increasing the porosity of the paste (as controlled by the initial w/s ratio), the conductivity increased; a result that was mainly attributed to an increase in the degree of hydrolysis of CKD constituents leading to an increased number of charge carriers.

The electrical conductance increased with increasing hydration temperature up to $50^{\circ} \mathrm{C}$, as the degree of initial hydrolysis of cement blend increases at higher temperatures.

The hydraulic reactivity of granulated slag and silica fume as activated by raw CKD was relatively high as compared with those activated by washed CKD; this was attributed to the presence of excess alkali content in the raw CKD.

Taha et al. [14] evaluated the possibility of recycling the waste materials. In particular, the usefulness of copper slag (CS) and CKD was investigated for use as partial replacements for Portland cement in mortar mixtures. The physical properties of OPC, CS, and CKD are presented in Table 2 while the chemical analysis is presented in Table 3.

Various mortar mixtures were prepared using combinations of sand, water, lime, OPC, CS, and CKD. A water-tobinder ratio of 0.4 was used. The specified cube compressive strength values for cement mortars were 15 and $23 \mathrm{MPa}$ at 3 and 7 days, respectively. The compressive strengths for cement mortars obtained using CS alone or when using lime as an activator were generally lower than the compressive strength of the control mix. However, the
Table 2

Physical properties of copper slag, ordinary Portland cement and cement kiln dust [14]

\begin{tabular}{llll}
\hline Property & $\begin{array}{l}\text { Copper } \\
\text { slag }\end{array}$ & $\begin{array}{l}\text { Ordinary Portland } \\
\text { cement }\end{array}$ & $\begin{array}{l}\text { Cement kiln } \\
\text { dust }\end{array}$ \\
\hline $\begin{array}{l}\text { Fineness }\left(\mathrm{cm}^{2} / \mathrm{g}\right) \\
\text { Specific gravity }\end{array}$ & 1.261 & 3.357 & 4.824 \\
$\begin{array}{l}\text { Initial setting time } \\
\text { (min) }\end{array}$ & 250 & 3.15 & 2.4 \\
& & 110 & 150 \\
\hline
\end{tabular}

Table 3

Chemical composition of copper slag, ordinary Portland cement and cement kiln dust [14]

\begin{tabular}{|c|c|c|c|}
\hline Constituent $(\%)$ & $\begin{array}{l}\text { Copper } \\
\text { slag }\end{array}$ & $\begin{array}{l}\text { Ordinary Portland } \\
\text { cement }\end{array}$ & $\begin{array}{l}\text { Cement kiln } \\
\text { dust }\end{array}$ \\
\hline $\mathrm{SiO}_{2}$ & 33.05 & 20.85 & 15.84 \\
\hline $\mathrm{Al}_{2} \mathrm{O}_{3}$ & 2.79 & 4.78 & 3.57 \\
\hline $\mathrm{Fe}_{2} \mathrm{O}_{3}$ & 53.45 & 3.51 & 2.76 \\
\hline $\mathrm{CaO}$ & 6.06 & 63.06 & 63.76 \\
\hline $\mathrm{MgO}$ & 1.56 & 2.32 & 1.93 \\
\hline $\mathrm{SO}_{3}$ & 1.89 & 2.48 & 1.65 \\
\hline $\mathrm{K}_{2} \mathrm{O}$ & 0.61 & 0.55 & 2.99 \\
\hline $\mathrm{Na}_{2} \mathrm{O}$ & 0.28 & 0.24 & 0.33 \\
\hline $\mathrm{TiO}_{2}$ & 0 & 0.25 & 0.48 \\
\hline $\mathrm{Mn}_{2} \mathrm{O}_{3}$ & 0.06 & 0.05 & 0.07 \\
\hline $\mathrm{Cl}$ & 0.01 & 0.01 & 1.09 \\
\hline Loss on ignition & 0 & 1.75 & 5.38 \\
\hline Insoluble residue & 0 & 0.21 & 0 \\
\hline $\mathrm{Al}_{2} \mathrm{O}_{3}+\mathrm{SiO}_{2}+\mathrm{Fe}_{2} \mathrm{O}_{3}$ & 89.29 & 29.14 & 22.17 \\
\hline
\end{tabular}

use of CKD as a partial replacement for OPC or as an activator for CS resulted in an improvement in the compressive strength of cement mortars at all curing ages. The compressive strength was higher than that of the control mix. The data developed in that study indicated that CKD would perform better than CS in concrete when utilized as a partial replacement of Portland cement. Among all mixes, the mix containing $5 \%$ CKD $+95 \%$ OPC yielded the highest 90 days compressive strength of $41.7 \mathrm{MPa}$ in comparison with $40 \mathrm{MPa}$ for the mix containing $1.5 \% \mathrm{CKD}+13.5 \%$ $\mathrm{CS}+85 \%$ OPC $[14]$

The possibility of utilizing CKD as an activator for granulated ground blast furnace slag (GGBFS) was investigated by Konsta-Gdoutos and Shah [15]. Binary blends containing slag and CKDs from different sources were characterized and compared in terms of the rates of heat evolution and strength development, hydration products, and time of initial setting.

Four different types of CKDs and a GGBFS were selected. The chemical composition and physical properties of the materials are given in Table 4. Compositions of the individual components were determined by X-ray fluorescence spectroscopy. The slag met the classification requirements of ASTM C 989 for Grade 100. The specific gravity was 2.90 and the Blaine specific surface was $4460 \mathrm{~cm}^{2} / \mathrm{g}$. Results from X-ray diffraction analysis indicated that the slag consisted mainly of a glassy phase. 
Table 4

Results of oxide analysis of CKD and GGBFS by XRF [15]

\begin{tabular}{lccccc}
\hline Constituent (\%) & CKD (E) & CKD (P) & CKD (A) & CKD (X) & GGBS \\
\hline $\mathrm{SiO}_{2}$ & 14.67 & 15.7 & 11.5 & 8.96 & 31.96 \\
$\mathrm{Al}_{2} \mathrm{O}_{3}$ & 5.06 & 5.061 & 4.68 & 2.667 & 10.31 \\
$\mathrm{Fe}_{2} \mathrm{O}_{3}$ & 3.46 & 2.58 & 2.04 & 2.21 & 1.42 \\
$\mathrm{CaO}$ & 56.99 & 45.5 & 50.2 & 48.6 & 45.98 \\
$\mathrm{MgO}$ & 1.04 & 2.33 & 1.34 & 3.141 & 7.02 \\
$\mathrm{SO}_{3}$ & 8.45 & 5.68 & 16.7 & 7.23 & 2.13 \\
$\mathrm{~K}_{2} \mathrm{O}$ & 6.073 & 5.33 & 5.86 & 6.81 & 0.31 \\
$\mathrm{Na}_{2} \mathrm{O}$ & 0.6 & 0.89 & 1.015 & 0.54 & 0.26 \\
$\mathrm{Alkali} \mathrm{equivalent}$ & 4.60 & 4.40 & 4.871 & 5.021 & 0.38 \\
$\mathrm{P}_{2} \mathrm{O}_{5}$ & 0.102 & 0.077 & 0.085 & - & 0.02 \\
$\mathrm{Cl}^{-}$ & 0.532 & 1.802 & 0.732 & 1.40 & - \\
Loss on ignition & 15.10 & 25.5 & 9.56 & 17.92 & 0.2 \\
\hline
\end{tabular}

It was reported that the combination of both chemical and physical characteristics of CKD is critical in controlling the mechanisms of activation of GGBFS, the properties of the hydration products, and the rate of strength development. Adequate initial alkali concentration and the presence of sulfates have a decisive influence on slag activation and initial hydration. Further, hydration and the formation of hydration products, leading to higher rate of strength development, are determined by the availability of $\mathrm{Ca}^{2+}$ provided by the free lime content of the CKD.

Compressive strength of all four CKD-slag blends increased with curing time, indicating slag activation by the CKD and the formation, precipitation, and accumulation of products of hydration, similar to the ones found in typical OPC and OPC-slag systems. The variation of the chemical composition of the CKDs resulted in the formation of different hydration products at early hydration ages. At later ages, $\mathrm{C}-\mathrm{S}-\mathrm{H}$ gel and the stable sulfoaluminate hydrate (ettringite) were the major hydration products for all the CKD-slag blends. In cases where the free-lime content of the CKD exceeds the requirements for the pozzolanic reaction, the remaining unreacted crystalline $\mathrm{Ca}(\mathrm{OH})_{2}$ may show a slight decrease in the strength development and possibly affect some durability properties [15].

The calcium carbonate particles of the CKDs were essentially inert and did not participate in the hydration reaction. CKDs with water-soluble alkali content higher than $2 \% \mathrm{Na}_{2} \mathrm{O}$ equivalent, low levels of carbonates, and free-lime contents greater than $5 \%$ per mass of slag were considered more reactive and resulted in blends with higher strength developments. The authors, however, indicated that the volume stability of any CKD-slag blend using a dolomitic CKD needs further research [15].

Shoaib et al. [16] evaluated the influence of CKD substitution on the mechanical properties of concrete. Materials used in that research were "untreated" raw CKD which was collected from electrostatic precipitators, OPC, BFS, and sulfate resisting cement (SRC). The chemical analysis of the materials used is given in Table 5. A total of 135 cubes and 135 cylinders were tested to study the effect of replacement of CKD on the mechanical behavior of concrete. The following variables were considered:
Table 5

The chemical composition of materials used [16]

\begin{tabular}{lcccr}
\hline Constituent (\%) & OPC & BFSC & SRC & CKD \\
\hline $\mathrm{SiO}_{2}$ & 21.42 & 25.8 & 20.9 & 11.95 \\
$\mathrm{Al}_{2} \mathrm{O}_{3}$ & 3.3 & 5.25 & 5.26 & 1.12 \\
$\mathrm{Fe}_{2} \mathrm{O}_{3}$ & 5.23 & 7.71 & 4.02 & 2.45 \\
$\mathrm{CaO}$ & 62.70 & 57.4 & 63.88 & 49.75 \\
$\mathrm{MgO}$ & 2.40 & 2.73 & 2.50 & 1.86 \\
$\mathrm{SO}_{3}$ & 2.35 & 3.0 & 2.36 & 6.35 \\
$\mathrm{~S}$ & - & 1.81 & 1.95 & - \\
$\mathrm{Na}_{2} \mathrm{O}$ & 2.41 & 2.13 & 0.46 & 3.87 \\
$\mathrm{~K}_{2} \mathrm{O}$ & 0.45 & 0.29 & 0.22 & 2.66 \\
$\mathrm{Cl}^{-}$ & 0 & - & - & 6.80 \\
Loss on ignition & 1.22 & 1.08 & 0.91 & 17.92 \\
\hline
\end{tabular}

1. Types of cement (OPC, BFSC, and SRC);

2. Percentage of replacement of CKD as ratio to cement used $(0 \%, 10 \%, 20 \%, 30 \%$, and $40 \%)$, and

3. Testing period of concrete $(1,3$, and 6 months).

Three mixes with three different types of cements were prepared. The three mixes having the same mix proportions ( 1 cement, 1.9 sand, 3.52 gravel and $0.5 \mathrm{w} / \mathrm{c}$ ratio), and the cement content used in the three mixes was $350 \mathrm{~kg} / \mathrm{m}^{3}$.

With increasing CKD content, generally, the ultimate compressive as well as tensile strengths decreased for OPC concrete; a slight increase in strength was observed for BFSC and some enhancement in strength of SRC, compared with free cement percent. Also, it was found that the high limit for substitution was not more than $30 \%$ for SRPC, and $20 \%$ for BFSC, and $10 \%$ for OPC which gave high ultimate compressive strength for SRPC and BFSC, and a critical value for OPC, respectively. Generally, it could be said that direct replacement (mixing) of CKD with SRPC or BFSC was more effective than recycling of CKD with cement raw materials, which forms unfavored clinker phase during firing in cement kilns, which is attributed to the effect of high alkalinity content in the dust on the nature of clinker phases.

Heikal et al. [17] investigated Portland cement clinker, BFS, and CKD composites. Three blends of slag cement were prepared. Each blend was mixed with 2.5, 5.0, 7.5, and $10.0 \mathrm{mass}^{\circ}$ CKD. The physical properties of cement pastes, including setting times, electrical conductivity, and fluidity were studied. The chemical composition of these raw materials is given in Table 6 . The mix proportions are shown in Table 7 . The required water for normal consistency and setting times were determined according to relevant ASTM standard test procedures.

The authors reported that the rheological properties of Portland cement clinker were enhanced (which decreased the torque viscosity) by partial replacement of ground granulated blast furnace slag [17]. CKD affected the rheological properties of Portland cement clinker/granulated slag composites and it depended on its amount as well as mix composition. 
Table 6

Chemical composition of OPC, slag and CKD [17]

\begin{tabular}{llll}
\hline Constituent $(\%)$ & Portland cement & Granulated slag & Cement kiln dust \\
\hline $\mathrm{SiO}_{2}$ & 21.26 & 37.3 & 13.37 \\
$\mathrm{Al}_{2} \mathrm{O}_{3}$ & 5.53 & 13.5 & 3.36 \\
$\mathrm{Fe}_{2} \mathrm{O}_{3}$ & 3.60 & 0.85 & 2.29 \\
$\mathrm{CaO}$ & 64.7 & 38.60 & 42.99 \\
$\mathrm{MgO}$ & 1.25 & 3.00 & 1.90 \\
Loss on ignition & 0.52 & - & 15.96 \\
$\mathrm{Cl}$ & 0.0068 & 0.0071 & 7.50 \\
Free lime & 0.75 & - & 2.59 \\
Surface area & 3300 & 3200 & 3700 \\
\hline
\end{tabular}

Table 7

Proportions for OPC and BFS mixtures [17]

\begin{tabular}{lll}
\hline $\begin{array}{l}\text { Mix } \\
\text { designation }\end{array}$ & $\begin{array}{l}\text { Portland cement clinker } \\
(\%)\end{array}$ & $\begin{array}{l}\text { Granulated blast furnace slag } \\
(\%)\end{array}$ \\
\hline M.1 & 70 & 30 \\
M.2 & 50 & 50 \\
M.3 & 30 & 30 \\
\hline
\end{tabular}

The setting time of Portland slag cement paste was extended with slag content. Further, the presence of CKD affected the location and height of the conductivity peaks, which increased the intensity of the conductivity maximum. By increasing the CKD from 2.5 to 7.5 mass $\%$, the conductivity maximum increased; with further addition $(10 \operatorname{mass} \%)$, the height of the conductivity maximum decreased [17].

Udoeyo and Ridnap [18] reported the results of a study on the properties of hollow sandcrete blocks with CKD as an additive and as a replacement of OPC. When CKD was used as a replacement for cement, the compressive strength and density of blocks generally decreased with higher replacement levels of OPC by CKD, while the percentage water absorption of blocks increased with higher replacement levels. On the other hand, when CKD was used as an addition, within the investigated levels, an improvement in the compressive strength of up to $54 \%$ was observed. The density of blocks also increased with higher CKD content as an additive, while the water absorption of blocks showed a reverse trend.

Babiaan et al. [19] investigated the effect of mechanochemical activation on the reactivity of CKD-FA systems. Combinations of CKD and FA were used to develop cementitious materials through mechano-chemical activation. Mixture combinations made with two different proportions were subjected to various grinding regimes to activate the material. Properties, including particle size distribution, initial time of set, heat of hydration, and compressive strength of the new material were determined.

Mechanical grinding resulted in mechano-chemical activation of the material, with vibratory grinding being more effective than ball mill grinding. Activation was confirmed through X-ray diffraction analysis and no correlation was found between activation and the mean particle size of the material. Although not all the properties of the material tested were comparable to those of Portland cement, the results indicated the potential for significant improvement.

Pierce et al. [20] evaluated the fluid and hardened state properties of controlled low-strength materials (CLSM) with CKD as the primary binding agent. Laboratory-prepared mixtures with CKD:fine aggregate ratios of $1: 12$, $1: 6$, and $1: 1$ were investigated by varying the water/binder ratio $(\mathrm{w} / \mathrm{b})$ from 0.95 to 1.10 . Flowability, volume stability (bleeding), setting time, mass density, and 28-day unconfined compressive strength were measured for each mixture. The results revealed that high flowability and setting times within $24 \mathrm{~h}$ could be achieved with most mixtures, although the bleeding levels were higher than normal. Fifteen different CKD-CLSM mixtures were proportioned to produce average strengths ranging from 34 to $460 \mathrm{kPa}$. The wide range of strengths was significant for two reasons. First, all mixtures are considered to be excellent based on their 28-day strengths. Second, the stress-strain behavior of these mixtures was representative of soil types ranging from soft clays to very stiff clays. The authors noted that CKD can be beneficially added to produce a very low-strength material that offers comparable strengths to soils used for conventional fills and many other lowstrength applications [20].

\section{Experimental work}

\subsection{Materials}

The chemical composition of CKD investigated by the authors is shown in Table 8. The concentration of alkalis and chloride in the CKD is more than the allowable value. The sulfate content is within the acceptable limits.

Table 8

Chemical analysis of CKD

\begin{tabular}{|c|c|}
\hline Constituent & Weight $(\%)$ \\
\hline $\mathrm{CaO}$ & 49.3 \\
\hline $\mathrm{SiO}_{2}$ & 17.1 \\
\hline Chloride & 6.90 \\
\hline Loss on ignition & 15.8 \\
\hline $\mathrm{Al}_{2} \mathrm{O}_{3}$ & 4.24 \\
\hline $\mathrm{Fe}_{2} \mathrm{O}_{3}$ & 2.89 \\
\hline $\mathrm{K}_{2} \mathrm{O}$ & 2.18 \\
\hline $\mathrm{MgO}$ & 1.14 \\
\hline $\mathrm{Na}_{2} \mathrm{O}$ & 3.84 \\
\hline $\mathrm{P}_{2} \mathrm{O}_{5}$ & 0.12 \\
\hline Equivalent alkalis $\left(\mathrm{Na}_{2} \mathrm{O}+0.658 \mathrm{~K}_{2} \mathrm{O}\right)$ & 5.27 \\
\hline $\mathrm{SO}_{3}$ & 3.56 \\
\hline $\mathrm{BaO}(\mu \mathrm{g} / \mathrm{g}(\mathrm{ppm}))$ & 78.2 \\
\hline $\mathrm{Cr}_{2} \mathrm{O}_{3}$ & 0.011 \\
\hline $\mathrm{CuO}$ & 0.029 \\
\hline $\mathrm{NiO}$ & 0.012 \\
\hline $\mathrm{SrO}$ & 0.37 \\
\hline $\mathrm{TiO}_{2}$ & 0.34 \\
\hline $\mathrm{V}_{2} \mathrm{O}_{5}$ & 0.013 \\
\hline $\mathrm{ZnO}(\mu \mathrm{g} / \mathrm{g}(\mathrm{ppm}))$ & 65.8 \\
\hline $\mathrm{ZrO}_{2}$ & 0.011 \\
\hline
\end{tabular}




\subsection{Mixture design and properties}

The properties of cement incorporating CKD were evaluated by preparing two mixtures. In the first mixture, $5 \%$ cement was replaced with CKD while the second mixture contained $10 \%$ CKD and $90 \%$ cement. The following properties were evaluated:

(i) Normal consistency, according to ASTM C 187 [21];

(ii) Time of setting, according to ASTM C 191 [22];

(iii) Compressive strength, according to ASTM C 109 [23];

(iv) Auto clave expansion, according to ASTM C 151 [24]; and

(v) Drying shrinkage, according to ASTM C 157 [25].

\section{Results and discussion}

The normal consistency of Type I cement and Type I cement plus CKD mixtures is shown in Table 9. The water requirement for all the mixtures did not vary very much, being in the range of $24.6-24.9 \%$. This indicates that incorporation of up to $10 \%$ CKD in cement, as partial replacement of cement, did not increase the water requirement.

The initial and final setting times of Type I cement and Type I cement plus CKD is summarized in Table 10. The initial setting time decreased with the addition of CKD to Type I cement. The initial time of set in the Type I, Type I plus $5 \%$ CKD, and Type I plus $10 \%$ CKD cements was 175,165 , and $155 \mathrm{~min}$, respectively. These values are more than the specified value of $45 \mathrm{~min}$ by ASTM C $150[26]$.

The final setting time also decreased with the addition of CKD, although not significantly. The final setting time in the Type I and Type I plus CKD cements was within the

Table 9

Normal consistency of Type I cement and Type I cement plus CKD

\begin{tabular}{ll}
\hline Cement & Water content, $\%$ by weight of cement \\
\hline Type I & 24.6 \\
Type I $+5 \%$ CKD & 24.9 \\
Type I $+10 \%$ CKD & 24.9 \\
\hline
\end{tabular}

Table 10

Time of setting of Type I and Type I cement plus CKD

\begin{tabular}{|c|c|c|c|c|}
\hline Cement & $\begin{array}{l}\text { Initial setting } \\
\text { time (min) }\end{array}$ & $\begin{array}{l}\text { ASTM C } 150 \\
\text { limit (min) }\end{array}$ & $\begin{array}{l}\text { Final setting } \\
\text { time }(\mathrm{min})\end{array}$ & $\begin{array}{l}\text { ASTM C } 150 \\
\text { limit (min) }\end{array}$ \\
\hline Type I & 175 & 45 Minimum & 256 & 375 \\
\hline $\begin{array}{l}\text { Type } \\
\qquad \begin{array}{l}I+5 \% \\
\text { CKD }\end{array}\end{array}$ & 165 & & 250 & Maximum \\
\hline $\begin{array}{l}\text { Type } \\
\qquad \begin{array}{l}\text { I }+10 \% \\
\text { CKD }\end{array}\end{array}$ & 155 & & 238 & \\
\hline
\end{tabular}

allowable value of $375 \mathrm{~min}$ specified by ASTM C 150 [26]. The decrease in the initial and final setting times may be ascribed to the high amounts of alkalis and lime in $\mathrm{CKD}$, which accelerate the hydration process thereby leading to faster setting than in cements without CKD.

The autoclave expansion of Type I and Type I plus CKD cement mortar specimens is summarized in Table 11. The expansion of CKD cements was more than that of Type I cement, and it increased with the quantity of CKD in the cement. However, these values are much lower than $0.8 \%$ allowed by ASTM C 150 [26].

The compressive strength of Type I and Type I plus CKD cement mortar specimens is shown in Table 12 . The compressive strength of CKD cements was more than that of Type I cement and it increased with the quantity of CKD in the cement. This is an encouraging result, as CKD could be utilized as a partial replacement of cement, if it could be shown that the high alkalinity and the chloride and sulfate concentrations in CKD do not adversely affect durability of concrete.

The drying shrinkage of Type I and Type I plus CKD cement mortar specimens is shown in Table 13. As expected, the drying shrinkage increased with time in all the specimens. The drying shrinkage of Type I plus CKD was more than that of Type I cement; increasing with the quantity of CKD replacement in the Type I cement. ASTM C 150 does not place any restrictions on the drying shrinkage values.

The data in Tables 9-13 indicate that incorporation of up to $10 \% \mathrm{CKD}$, as a partial replacement of cement, does not adversely affect the properties of the resulting cement. The CKD-Portland cement mixture meets most of the physical requirements specified in ASTM C 150 and its compressive strength is more than that of the parent Type I cement. However, the concomitant effect of high alkalinity and high chloride and sulfate concentration in CKD on the pore solution composition, and consequently, on concrete durability needs to be evaluated.

Table 11

Auto clave expansion of Type I cement and Type I cement plus CKD

\begin{tabular}{lll}
\hline Cement & Average expansion $(\%)$ & ASTM C 150 limit $(\%)$ \\
\hline Type I & 0.00752 & $0.8 \mathrm{Max}$. \\
Type I $+5 \%$ CKD & 0.01295 & \\
Type I $+10 \%$ CKD & 0.0373 & \\
\hline
\end{tabular}

Table 12

Compressive strength of Type I cement and Type I cement plus CKD

\begin{tabular}{lllll}
\hline \multirow{2}{*}{ Cement } & \multicolumn{4}{l}{ Average compressive strength (MPa) } \\
\cline { 2 - 5 } & 1 Day & 3 Days & 7 Days & 28 Days \\
\hline Type I & 6.31 & 15.04 & 22.93 & 33.17 \\
Type I + 5\% CKD & 8.09 & 21.60 & 27.60 & 34.79 \\
Type I + 10\% CKD & 8.43 & 22.71 & 27.69 & 36.89
\end{tabular}


Table 13

Average drying shrinkage of Type I cement and Type I cement plus CKD

\begin{tabular}{|c|c|c|c|c|c|c|c|}
\hline \multirow[t]{2}{*}{ Cement } & \multicolumn{7}{|c|}{ Average drying shrinkage (\%) } \\
\hline & 7 Days & 14 Days & 21 Days & 28 Days & 45 Days & 60 Days & 75 Days \\
\hline Type I & 0.0380 & 0.0528 & 0.0620 & 0.0694 & 0.0739 & 0.0811 & 0.0847 \\
\hline Type $\mathrm{I}+5 \%$ CKD & 0.0481 & 0.0742 & 0.0886 & 0.0918 & 0.0942 & 0.0977 & 0.1008 \\
\hline Type I $+10 \%$ CKD & 0.0532 & 0.0889 & 0.0924 & 0.1043 & 0.1098 & 0.1144 & 0.1173 \\
\hline
\end{tabular}

\section{Conclusions}

Tests conducted by the authors using cement and CKD mortar mixtures show that CKD can be used in cement mortar without affecting the requirements stipulated by ASTM C 150 for Portland cement. Tests conducted on Type I cement with CKD replacement of up to $10 \%$ indicated the following:

(i) No increase in water requirement;

(ii) The initial and final setting times of CKD cement mixtures are slightly decreased but they are well within the ASTM C 150 requirements;

(iii) Autoclave expansion is increased but it is less than the maximum ASTM C 150 [26] requirement of $0.8 \%$;

(iv) Early age and 28-day compressive strength of CKDcement mortar is higher than that of Type I cement mortar; and

(v) The shrinkage of CKD-cement mortar increases with an increase in the quantity of CKD.

The concomitant effect of high alkalinity and high chloride sulfate concentrations in CKD on concrete durability needs to be evaluated.

\section{Acknowledgements}

Authors acknowledge the support of King Fahd University of Petroleum and Minerals and the Arabian Cement Company, Saudi Arabia.

\section{References}

[1] Aidan C, Trevor C. Cement kiln dust. Concrete 1995(October):40-2.

[2] A new stone age: the making of portland cement. Portland Cement Association, Skokie, Illinois, 1992.

[3] Bhatty JI. Alternative uses of cement kiln dust. RP327 Portland Cement Association, Skokie, Illinois, USA, 1995.

[4] El-Sayed HA, Gabr NA, Hanafi S, Mohran MA. Re-utilization of bypass kiln dust in cement manufacture. In: Proceedings of the international conference on blended cement in construction, Sheffield, UK, 1991.

[5] Batis G, Rakanta E, Sideri E, Chaniotakis E, Papageorgiou A. Advantages of simultaneous use of cement kiln dust and blast furnace slag. In: Proceedings of the international conference on challenges of concrete construction, University of Dundee, Dundee, UK, 2002.

[6] Bhatty MSY. Use of cement kiln dust in blended cements. World Cem 1984;15(4):126-8. pp. 131-134.

[7] Bhatty MSY. Use of cement kiln dust in blended cements-Alkaliaggregate reaction expansion. World Cem 1985;16(10):386-91.

[8] Bhatty MSY. Properties of blended cements made with Portland cement, cement kiln dust, fly ash, and slag. In: Proceedings of the international congress on the chemistry of cement, Communications Theme 3, vol. 1.04, Brazil: 1986. pp. 118-127.

[9] Dyer TD, Halliday JE, Dhir RK. An investigation of the hydration chemistry of ternary blends containing cement kiln dust. J Mater Sci 1999;34(20):4975-83.

[10] Abo-El-Enein SA. Utilization of cement kiln dust in cement industry and building products. 1997

[11] Sri Ravindrarajah R. Usage of cement kiln dust in concrete. Int J Cement Comp Lightweight Concrete 1982;4(2):95-102.

[12] Wang K, Shah SP, Alexander M. Effects of curing temperature and $\mathrm{NaOH}$ addition on hydration and strength development of clinkerfree CKD-fly ash binders. Cement Concrete Res 2004;34(2): 299-309.

[13] Salem Th M, Ragai Sh M. Electrical conductivity of granulated slagcement kiln dust-silica fume pastes at different porosities. Cement Concrete Res 2001;31(5):781-7.

[14] Taha R, Al-Rawas A, Al-Jabri K, Al-Harthy A, Hassan H, AlOraimi S. An overview of waste materials recycling in the Sultanate of Oman, Resources. Conserv Recycling 2004;41(4):293-306.

[15] Konsta-Gdoutos MS, Shah SP. Hydration and properties of novel blended cements based on cement kiln dust and blast furnace slag. Cement Concrete Res 2003;33(8):1269-76.

[16] Shoaib MM, Balaha MM, Abdel-Rahman AG. Influence of cement kiln dust substitution on the mechanical properties of concrete Cement Concrete Res 2000;30(3):371-7.

[17] Heikal M, Aiad I, Helmy IM. Portland cement clinker, granulated slag and by-pass cement dust composites. Cement Concrete Res 2002;32(11):1805-12.

[18] Udoeyo FF, Rindap PI. Cement kiln dust as a material for building blocks. Global J Eng Res 2002;1(1):73-8.

[19] Babiaan PM, Wang K, Mishulovish A, Bhattacharja S, Shah SP. Effect of mechano-chemical activation on reactivity of cement kiln dust-fly ash systems. ACI Mater J 2003;100(1):55-62.

[20] Pierce CE, Tripathi H, Travis BW. Cement kiln dust in controlled low-strength materials. ACI Mater J 2003;100(6):455-62.

[21] ASTM C187. Standard test method for normal consistency of hydraulic cement. Annual Book of ASTM Standards, vol. 4.01. Conshohocken, PA: American Society for Testing and Materials; 2004.

[22] ASTM C191. Standard test method for normal consistency by Vicat needle. Annual Book of ASTM Standards, vol. 4.01. Conshohocken, PA: American Society for Testing and Materials; 2004.

[23] ASTM C109. Standard test method for compressive strength of hydraulic cement mortars. Annual Book of ASTM Standards, vol. 4.01. Conshohocken, PA: American Society for Testing and Materials; 2005.

[24] ASTM C151. Standard test method for autoclave expansion of hydraulic cement. Annual Book of ASTM Standards, vol. 4.01. Conshohocken, PA: American Society for Testing and Materials; 2005.

[25] ASTM C157. Standard test method for length change of hardened hydraulic cement, mortar, and concrete. Annual Book of ASTM Standards, vol. 4.02. Conshohocken, PA: American Society for Testing and Materials; 2006.

[26] ASTM C150. Standard specification for Portland cement. Annual Book of ASTM Standards, vol. 4.01. Conshohocken, PA: American Society for Testing and Materials; 2007. 